\title{
Smuggling in South Eastern Europe
}

\author{
Krunoslav Antoliš *
}

\section{Summary}

The smuggling of migrants, narcotics, and weapons are currently some of the most important issues in the sphere of international crime. At the same time, they are essential to the issue of fighting terrorism. By analyzing the overall situation and the factors that encourage global terrorism, this paper argues that, apart from the risk posed by socalled rogue states, unstable states should also be a focus in efforts to combat terrorism. The term unstable states is used here to refer to states facing many unsettled internal issues, and which are likely to become a bridge or an interface for terrorists in their worldwide operations. Typical issues in unstable states (also known as "transitional states") include high rates of organized crime, corruption, human trafficking, and trade in drugs and weapons; at the same time, such states are characterized by inefficient legal and governance structures, and weak central state power in general. According to this definition, a few countries in South Eastern Europe could be regarded as unstable states.

A systematic effort to discover the routes used by smugglers of all kinds is needed if states are to concentrate their limited resources on solving these problems. Yet, it will only be possible to make forward progress in this respect by coordinating the efforts of executive, legislative, and judicial authorities in these countries, with the support of non-governmental organizations (NGOs) and security experts of multinational corporations that currently deal with the transportation of people and goods. ${ }^{1}$ Professional support for this effort will require the implementation of the most recent scientific achievements and technologically advanced methods in uncovering smugglers and their cargos. ${ }^{2}$ The main goal of cooperative anti-trafficking and security efforts is the early detection and monitoring of all participants in a smuggling network. This achievement will create the conditions to deal with the network and its key strongholds — both physically and virtually—and to eliminate its vital infrastructure.

* Dr. Krunoslav Antoliš is an Assistant Professor in the Faculty of Business and Economics at the University of Zagreb. All statements made in this article are solely those of the author and in no way reflect the official positions or policies of the Republic of Croatia, Croatia's Government, or the Ministry of the Interior.

1 K. Antoliš, "Prerequisites for Systematic Fighting of Terrorism," presentation at the conference "National Security and Traffic Perspectives for the Republic of Croatia," Croatian Parliament, Zagreb (27-28 February 2006).

2 K. Antoliš, "Strategic Prerequisites for Partnership in Combating Terrorism," presentation at the conference "Establishing Referent Laboratory for Nuclear-Biological-Chemical Protection and System for Bio-monitoring in the Republic of Croatia,” at the Institute Ruđer Bošković, Zagreb (6 June 2006). 


\section{Smuggling Migrants}

The region of South Eastern Europe-particularly the states that gained independence or were established after the Warsaw Pact dissolved, as well as those that were set up after the dissolution of Yugoslavia - has been confronted with the unfamiliar challenges of the market economy. As a result of major irregularities in the course of the privatization of public property in these states, a new kind of capitalist emerged, one who now owned the former state property but did not have the knowledge needed to manage it in the context of a market economy. The poor management of newly privatized industries caused the decline of living standards for residents of South Eastern Europe. The war that resulted in the dissolution of Yugoslavia also created a significant wave of migration within the region, which caused a number of unwanted consequences, among them human trafficking, which has become a particularly critical issue. In order to understand the complexity of this situation, which has arisen remarkably rapidly, it is important to note the results of privatization in South Eastern Europe, including a high corruption rate, a low level of social sensitivity, a low standard of living in general, and a high unemployment rate-all of which are causes of regional migration $^{3}$ in countries such as the Ukraine, ${ }^{4}$ Moldova, Romania, Serbia, Macedonia, and Bosnia and Herzegovina. ${ }^{5}$

It should be stressed that, within the past five years, approximately 58,000 illegal aliens have been captured in Croatia, and their number is constantly increasing. However, official data of the Croatian Ministry of the Interior (MUP) indicates that only thirty-nine victims of human trafficking were identified in the same period (eight in 2002, eight in 2003, nineteen in 2004, and six in 2005). Recently, more significant efforts in preventing human trafficking have been made in Croatia. ${ }^{6}$ In the past six months, charges have been brought against twenty-two persons ${ }^{7}$ by the Office for Prevention of Corruption and Organized Crime (USKOK) in Croatia, on counts of trafficking over 150 persons from Albania, Serbia and Montenegro, and Macedonia along a route stretching from Bosnia through Zagreb, Istria, Slovenia, and Italy to Western Europe. Since it is located close to European Union (EU) member states, Croatia is a

3 National Intelligence Council, “Current World Illicit Trafficking,” available at www.dni.gov/ nic/PDF_GIF_global/current_illicit_trafficing.pdf.

4 The sex trafficking of Ukrainian women is a serious problem that has only recently been addressed; for more detail, see http://www.statistics.free-counter.co.uk/?count=vjesnik\&cmd= countryinfo\&action=ua.

5 Bosnia and Herzegovina are highly vulnerable to money-laundering activity, given the presence of a primarily cash-based and unregulated economy, weak law enforcement system, and endemic instances of corruption. Available at www.statistics.free-counter.co.uk/?count= vjesnik\&cmd=countryinfo\&action=ba.

6 At first, the Croatian government did not consider trafficking to be a major issue. See www.vjesnik.hr/html/2004/06/17/Clanak.asp?r=tem\&c=4.

7 Criminal proceedings were conducted against twenty-three defendants on charges of organized trafficking of foreign citizens abroad; see www.vjesnik.com/html/2002/07/08/ Clanak.asp $? \mathrm{r}=\mathrm{crn} \& \mathrm{c}=3$. 
magnet country for the victims of trafficking-mostly women who believe they are being transported to Western European countries for legitimate employment, only to be forced into prostitution instead. ${ }^{8}$

Despite the presence of human trafficking in the country, a large number of unsettled court proceedings have challenged Croatia's efficiency in fighting human trafficking. A large number of investigations have resulted in only a small number of criminals being sentenced for the crime of human trafficking, making Croatia's rate of success in prosecuting human trafficking extremely poor. This lack of enforcement encourages further trafficking along transit routes that go through Croatia.

Recent success by the Croatian police shows that human trafficking is regularly occurring through Croatia en route to Western Europe. For example, in June 2006, Croatian police found twenty-four Albanian and three Chinese citizens in a house in Sesvete, near Zagreb. Fifteen of them had crossed the border illegally, and magistrate court proceedings will be conducted against them. Of those found, twelve had already been arrested on 14 June as part of a group of twenty-one persons who had illegally crossed the border. At that time, the twelve had been ordered by the court to leave Croatia by 28 June. It turned out that the Chinese citizens were using false Korean documents to transit the country.

All transit channels for illegal migrants through the territory of Croatia have some commonalities, although they differ with regard to the locations and areas where illegal migrants enter or leave Croatia. The most widely used transit areas with respect to this criminal activity in Croatia are in Zagreb, Karlovac, Istria, Primosko-Goranska, Vukovarsko-Srijemska, Splitsko-Dalmatinska, and Dubrovačko-Neretvanska.

\section{Channels of Illegal Transport of Foreigners through Croatian Territory}

Serbia-Bosnia and Herzegovina-Croatia-Slovenia-Italy. This channel is used for smuggling illegal migrants from Kosovo, where they are picked up by regular bus lines that transport them from Priština to Bosnia and Herzegovina. Upon entering Bosnia, they continue on their way to Herzegovina and then to Croatia, ultimately heading for Split, Rijeka, Istria, the region of Unsko-Sanski Canton, and even to Zagreb. The second diverging path along this route is also used by Albanians, who start in Glina, Kosovo. From there, migrants are driven to Sarajevo, where they are accommodated temporarily. Then, they are taken by passenger cars to the region of Mostar and to the Croatian border (in the direction of Makarska), which they usually cross on foot. They travel to Rijeka, where they are given temporary accommodations, and then they are transported illegally to Slovenia to continue their way to the Italian border, which they also cross illegally.

Serbia-Croatia-Slovenia-Italy. Illegal migrants from the territories of Serbia and Montenegro enter Croatian territory near the border crossing of Bajakovo, continuing on their way to Zagreb. Then they move to the area of Žumberak, crossing the Slovenian border on foot.

8 Ines Jemrić, Violence Against Women; available at www.zinfo.hr/engleski/pages/research/ Nasiljenadzenama/engnasilje.htm. 


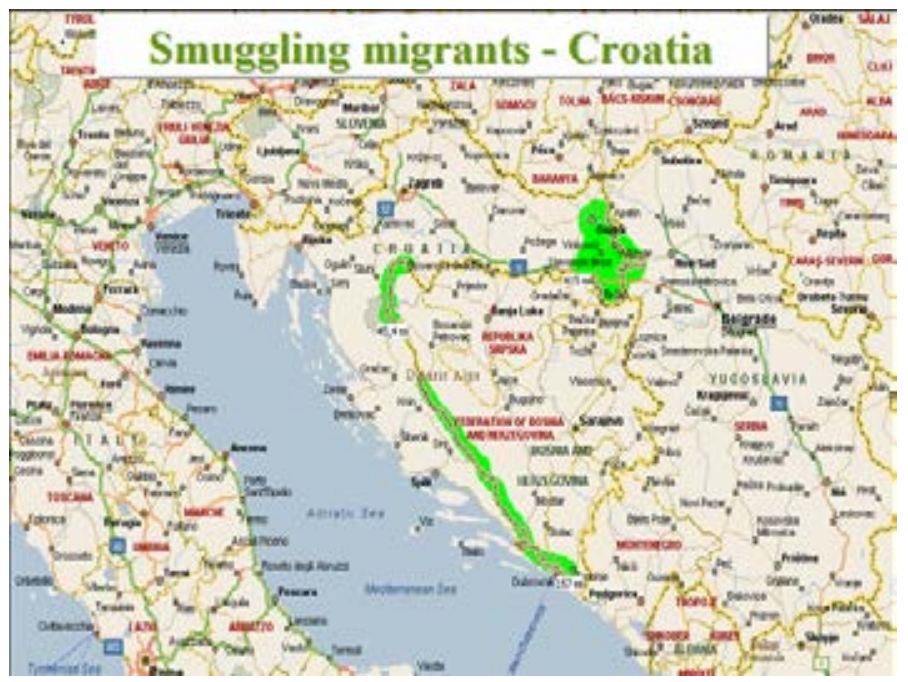

Figure 1: The most frequent points of illegal migration to Croatia

Bosnia and Herzegovina-Croatia-Slovenia-EU Member States. This channel is used by migrants from Africa and Asia, who fly into the country via the Sarajevo airport. It is also used by illegal migrants from the territory of Bosnia and Herzegovina. Illegal migrants from Sarajevo are transported to EU member states from three directions:

- Northern: This route leads across the Sava River to Croatia, and then to Western European states (primarily Germany and the Netherlands), taking the following routes:

1. Sarajevo-Gunja-Zagreb-Istria-Slovenia

2. Sarajevo-Brčko-Gunja-Zagreb-Slovenia

3. Sarajevo-Orašje-Županja-Zagreb-Ljubljana.

- Western: This route leads through Unsko-Sanski Canton to Croatia, and then toward Western European states (primarily Italy, Germany, and the Netherlands), taking a route from Sarajevo-Bihać/Velika Kladuša-Zagreb-Slovenia-Italy. Illegal migrants are transported by passenger cars or trucks to the area of UnskoSanski Canton, crossing the state border at Bihać or Velika Kladuša on foot. Then they continue their travels either towards Zagreb and Žumberak, crossing Slovenia's border on foot, or towards Rijeka and Slovenia's border.

- Southern: This route leads through the area of Herzegovina, continuing to either Montenegro or Croatia. Some of the illegal migrants are taken to Italy by speedboats, while others continue their way to the Slovenian border, taking the following routes: 


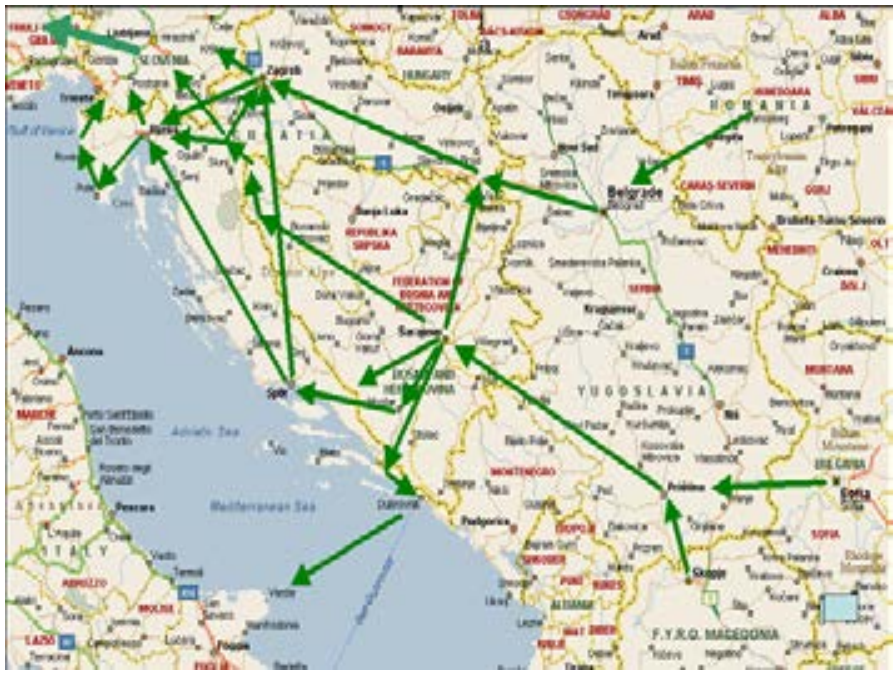

Figure 2: Illegal migrants from three directions

1. Sarajevo-Metković-Gradac-Zagreb-Slovenia

2. Sarajevo-Mostar-Split-Zagreb-Slovenia

3. Sarajevo-Mostar-Split-Rijeka-Slovenia

4. Sarajevo-Imotski-Zagreb-Pula-Poreč-Slovenia

5. Sarajevo-Neum-Dubrovnik-Italy.

Macedonia-Serbia-Croatia-Western European States. This channel is primarily used for transporting Albanians in small groups of five to ten people. They cross the borders between Croatia, Serbia, and Montenegro via the territory of the VukovarskoSrijemska region. Their destination is Slovenia, and afterwards a number of Western European countries.

Turkey-Bosnia and Herzegovina-Croatia-Slovenia-Italy. Illegal migrants originating from countries in Africa and Asia as well as Turkey (primarily Istanbul) come to Sarajevo and Tuzla by plane, and later continue their travels toward Croatia and Slovenia.

Turkey-Serbia-Bosnia and Herzegovina-Croatia-Slovenia-Italy. Illegal migrants that are transported along this route enter Croatia at the border with Bosnia and Herzegovina. This border is approximately 60 kilometers long; the main local border crossings are Maljevac and Ličko Petrovo Selo, which are located in the municipalities of Cetingrad and Rakovica, respectively. These migrants then cross the Žumberak area 
and other points near the border crossing at Jurovski Brod, Zakanje. They are then transported to Slovenia's border, or first to Rijeka and then to the Slovenian border.

China-Serbia-Bosnia and Herzegovina-Croatia-Slovenia-Italy. This channel is used for transporting migrants from China. In the early 1990s, most Chinese took the Russia-Belgrade-Croatia route, while in the past few years the dominant route has come from Belgrade, since many of the Chinese living in that area have had to leave after being denied the renewal of their visas. The illegal transportation of Chinese migrants through Croatian territory is performed in the following two ways:

- They enter Croatia illegally in order to leave for third countries. Illegal migrants come to Belgrade by plane and are then taken to Bosnia and Herzegovina by truck, entering Croatia by boat or on foot.

- They enter Croatia legally after obtaining an entry and exit visa appropriate for a business trip. These visas are issued on the basis of a letter of guarantee or invitation sent by companies registered in Croatia. After a short stay in Croatia, the migrants are illegally transported to Slovenia and Italy, often using Chinese passports of people who have already been granted residence in Italy.

Pakistan-Turkey-Serbia-Montenegro-Bosnia and Herzegovina-Croatia-SloveniaItaly. From the Karachi airport, Pakistani migrants fly to Istanbul. From there, they fly to Priština, and are then illegally transported to Montenegro via Peć and the hill of Čakor. (This channel is also used for transporting Albanians and residents of Serbia and Montenegro.) They continue their way towards Bosnia and Herzegovina, crossing the border near Mateljka and continuing on to the area of Bosanski Šamac. They enter Croatia near the Bosanski Šamac border crossing. Migrants are handed over at Sikirevci and Šamac. Afterwards, they are taken by passenger cars to the area of Čabar, entering Slovenia illegally on foot, and then traveling to Italy.

Pakistan-Turkey-Serbia-Croatia-Slovenia-Italy. Illegal immigrants fly from Pakistan via Istanbul to Priština, crossing the Serbian border illegally. They enter Croatia on foot near the Bajakovo border crossing. From there, they are taken by car to Zagreb and then to Čabar, illegally entering Slovenia.

Senegal-Croatia-Ljubljana-Italy. Illegal migrants from Senegal fly in to the airport either in Zagreb or in Split, using forged visas. Their transit to the Italian border is organized by illegal transport across the Slovenian border.

\section{Smuggling Narcotics}

The Republic of Croatia's geographic position has substantially contributed to the intensification of narcotics smuggling through its territory. Within this context, various criminal groups who organize the transport of narcotics have been identified, along with particular smuggling routes.

Depending on the type of narcotics and their place of origin, several smuggling methods have been established:

- Heroin is mainly smuggled by land routes (either by roads or by "wild" paths) 


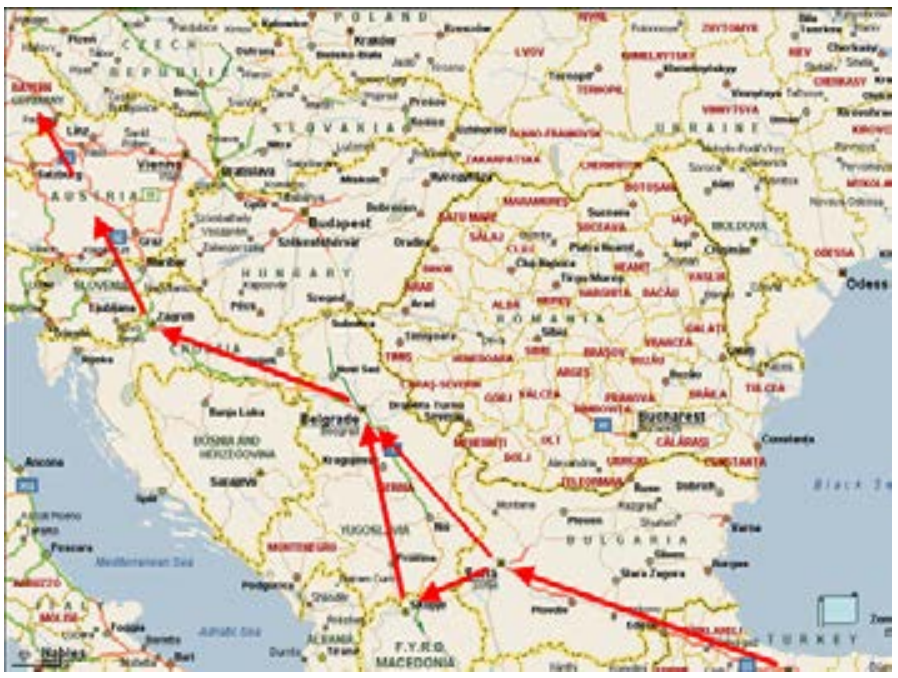

Figure 3: Western Balkan route via Belgrade (Turkey-Bulgaria-MacedoniaSerbia-Croatia-Slovenia-Western Europe)

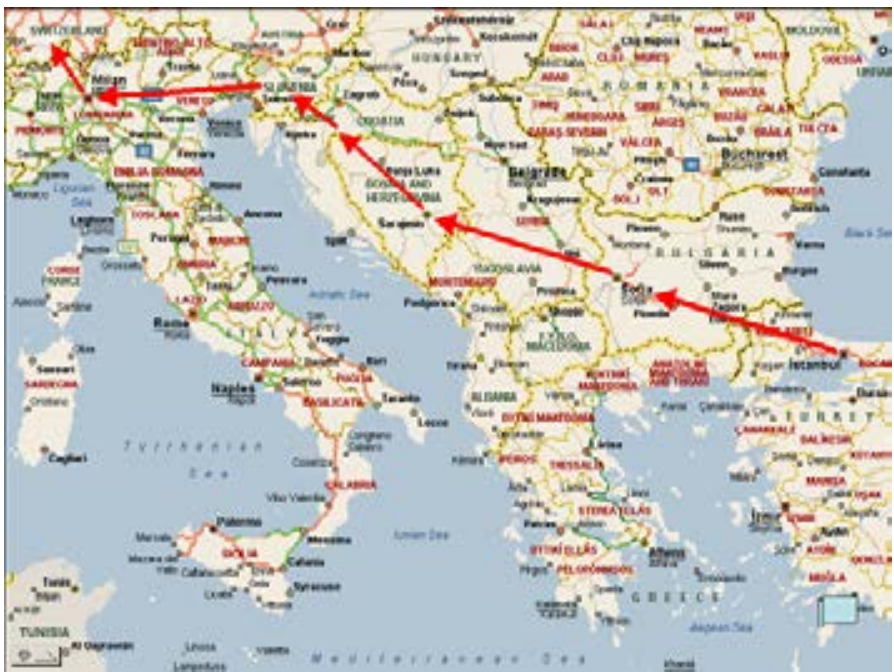

Figure 4: Western Balkan route via Kosovo and Bosnia and Herzegovina 
- Latin American cocaine is smuggled primarily by boat; it is also smuggled in smaller amounts by land and air.

A great deal of heroin destined for the Croatian and EU markets is smuggled through the so-called Balkan routes. The two main heroin smuggling routes from Turkey to Western Europe are the western and northern Balkan routes, which transit through Croatia. There is also a third route that bypasses Croatia.

\section{The Western Balkan Route}

This route is most often used by Turkish or Albanian transport companies in order to smuggle heroin. Some locations in Macedonia serve as starting points for smuggling. Narcotics are transported via Serbia and Montenegro, across the borders of eastern Croatia, and on to Croatian territory. Regular bus lines travel from Tetovo and Gostivar (Macedonia) via Niš, Belgrade (Serbia), Slavonski Brod, Zagreb, and Rijeka to Pula. Narcotics are smuggled in special tanks on the buses; each tank can contain more than 40 kilograms of heroin. Similar smuggling methods may be used by other transport companies, who transport passengers from Turkey to Germany via Croatia. In these cases, Croatia is merely a transit country, while Germany and other EU member states are the destination. After heroin is supplied in Turkey (generally in Istanbul), it is smuggled to Bulgaria, Serbia, and Montenegro, and is illegally brought to Croatia across the border at Bajakovo, ${ }^{9}$ Tovarnik, and Ilok. The importation of Turkish textiles is often used as a cover for smuggling narcotics.

Turkish and Albanian crime groups ${ }^{10}$ transport heroin and small amounts of cocaine from Istanbul via Bulgaria and Macedonia to Kosovo (specifically, the town of Peć), Montenegro (in the area of Sandžak and Rožaj), Serbia (Novi Pazar), Bosnia and Herzegovina (Sarajevo), Croatia, and on to EU member states in Western Europe.

Turkey-Bulgaria-Macedonia-Kosovo-Bosnia and Herzegovina-Croatia (Lika, Primorsko-Goranska county, Istria, Dalmatia)- Slovenia-Italy-Switzerland. This route is used to smuggle narcotics from Bosnia and Herzegovina to southern Croatia. The narcotics are smuggled to the Croatian coast, particularly the southern part, primarily in cooperation with organized crime groups from Bosnia and Herzegovina. Narcotics are marketed in the region of Banja Luka and transported across the Strmica border crossing, where they are then trafficked to Croatia.

The starting points for smuggling routes in Bosnia and Herzegovina include the wider region of Sarajevo and Banja Luka and Belgrade in Serbia. Drugs are mainly exported from five regions of Turkey along the routes described previously.

9 Reportedly, 5.5 kilograms of heroin were seized at the Bajakovo border crossing; see www.vecernji-list.hr/newsroom/blackchronicle/576325/index.do.

10 Assembly of Turkish-American Associations, "PKK and Terrorism: Drug Trafficking and Terrorist Organizations” (August 1998); available at www.ataa.org/ataa/ref/pkk/mfa/pkkdrugs.html. 


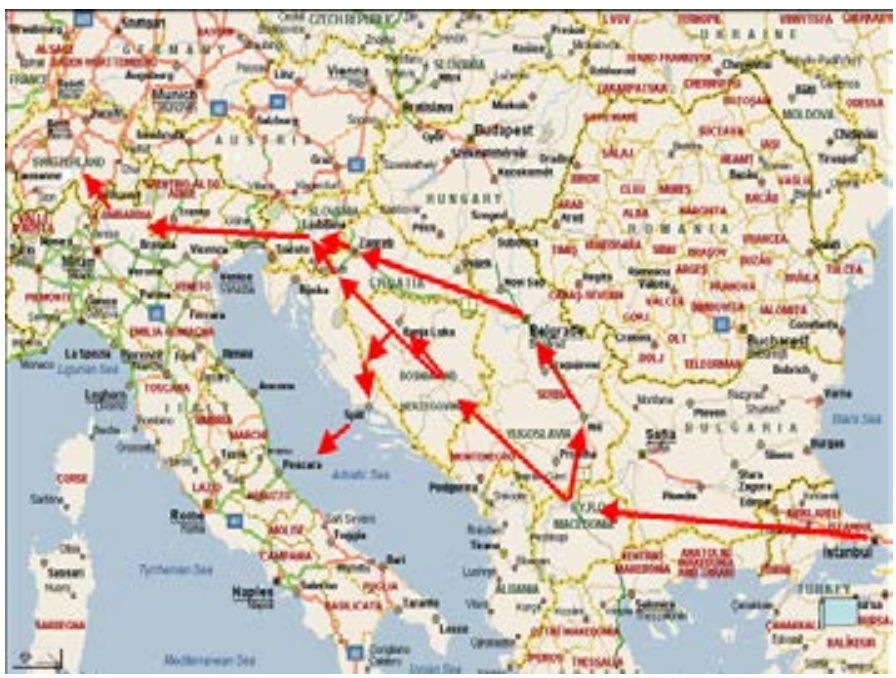

Figure 5: Narcotics smuggling routes from or through Bosnia and Herzegovina to Croatia

\section{Northern Balkan Route}

The northern Balkan route bypasses the Republic of Croatia, yet narcotics reach Croatia by one of the diverging branches of the route through Hungary, which is used by members of Albanian crime groups in Croatia. ${ }^{11}$

\section{Other Ways of Smuggling Narcotics through Croatia}

Cocaine is smuggled to Croatia mainly from countries in Latin America. It is transported by container ships that reach Croatian ports, or by small boats that may suitably enter marinas.

Some cocaine is smuggled along a western Balkan route, for which Istanbul is the point of departure. Smaller amounts of cocaine are smuggled in envelopes and transported by post delivery or by air. Synthetic drugs, such as Ecstasy, arrive in Croatia from a number of EU member states, including The Netherlands and Belgium, after transiting through states in Central Europe.

${ }^{11}$ Hungary is vulnerable to money laundering related to organized crime and drug trafficking. For more details, see www.statistics.free-counter.co.uk/?count=vjesnik\&cmd=countryinfo\& action=hu. 


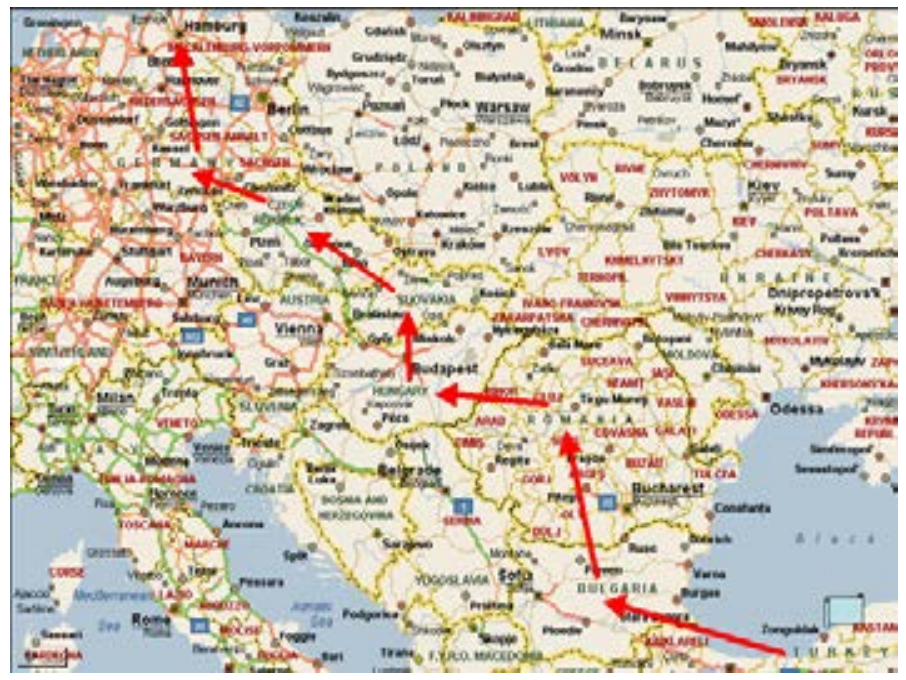

Figure 6: Northern Balkan route, bypassing the states on the territory of former Yugoslavia (Turkey-Bulgaria-Romania-Hungary-Slovakia-Czech RepublicWestern Europe)

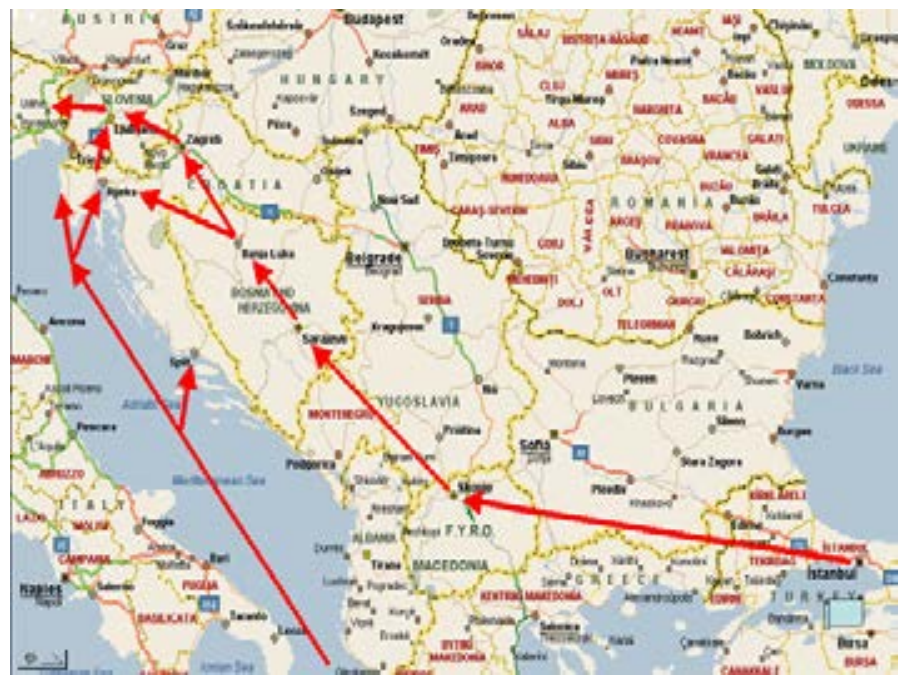

Figure 7: Cocaine smuggling routes—sea routes and one diverging road of the western Balkan route 


\section{Smuggling Weapons}

Weapons are smuggled mainly in cooperation with criminal groups from Bosnia and Herzegovina as well as Croatia. ${ }^{12}$ Due to the war in the former Yugoslavia in the 1990s, and the resulting surplus of weapons, Croatia has become (to some extent) the starting point for these criminal activities. Weapons and explosives are smuggled through Slovenia to Italian organized crime groups. There are also some indications that a portion of the weapons transported from Bosnia and Herzegovina through the Croatian port of Ploče are smuggled to Asian countries through the Middle East.

Croatian authorities have undertaken a number of successful actions against arms smugglers. For example, acting on a tip from U.S. intelligence, Croatian police in the port of Rijeka raided the cargo carrier Boka Star, which was supposedly loaded with activated charcoal. Instead, it was loaded with 208 metric tons of chemical ingredients - exactly the kind needed to produce the solid rocket fuel used in Iraqi Scud missiles. This connection was critical, U.S. government sources suggest, because the Boka Star was part of a well-monitored fleet that regularly sailed between Tivat, a Yugoslav naval base, and Syria, where a significant amount of cargo was trucked to Iraq. Evidence uncovered on board indicated that the Boka Star and its bogus cargo had been inaccurately issued documents several times by Yugoslav naval and customs officials. ${ }^{13}$

Some actions taken against illegal manufacturers of weapons in Croatia support the hypothesis that Croatia is not only a transit state for arms smuggling, but also a location of illegal manufacture. ${ }^{14}$ Croatian authorities-particularly the Office for Prevention of Corruption and Organized Crime, in cooperation with MUP and the Counterintelligence Agency (POA) - are expending great efforts to prevent such activities, not only within Croatian borders, but also in cooperation with other regional countries, including Slovenia. The most recent success was achieved in early June 2006, when twelve people were brought to the county court in Zagreb to be examined by the investigating judge on weapons charges. At the same time, criminal charges were brought against nineteen people by the Slovenian police, who had seized twenty-eight pieces of arms, ammunition, and explosives that were meant to be illegally sold both within the country and abroad. ${ }^{15}$

According to some open sources, another route for smuggling arms from Slovenia transits through the area surrounding Milan (Italy), takes a turn toward southern Italy,

12 Alenko Zornija, "Weapons Smugglers under Protection of BH Politicians?” Vjesnik (3 December 2001); available at www.hsp1861.hr/vijesti1/011203az.htm.

13 David Marash, "Saddam's Serb Supplier: How our Last Enemy Has Been Arming our Next One,” Washington Monthly (March 2003); available at www.findarticles.com/p/articles/ mi_m1316/is_2_35/ai_98829848.

14 "Illegal Weapons Manufacture Discovered in Zagorje;" available at http://vijesti.hrt.hr/ vijesti/ShowArticles.aspx?ArticleId=11070.

15 "Weapons Smugglers are Held in 24-hour Custody"; available at www.net.hr/vijesti/page/ 2006/06/08/0320006.html. 


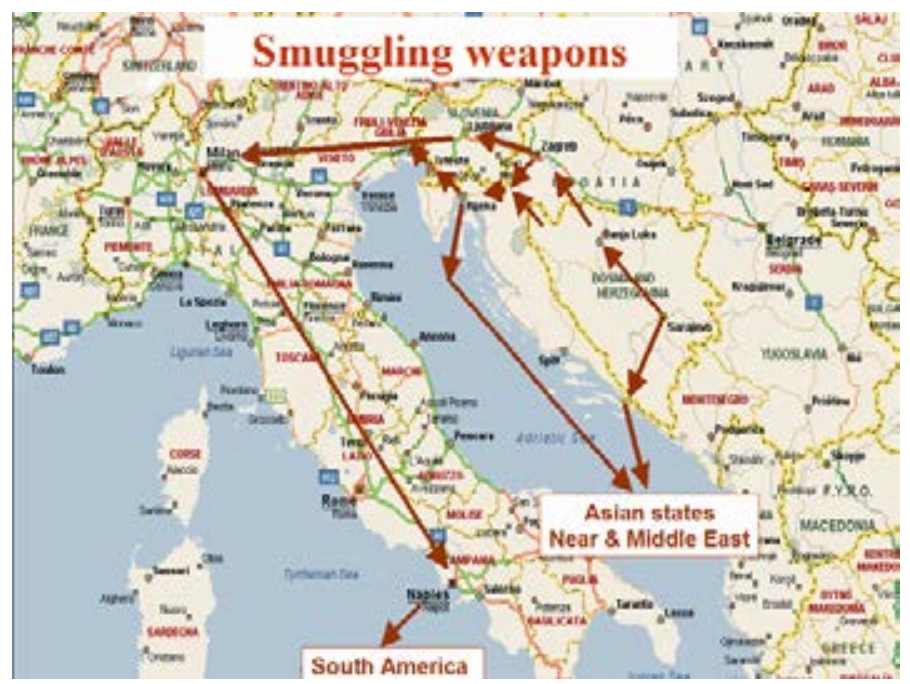

Figure 8: Weapon smuggling routes (BiH and Croatia-Slovenia-Italy-EU or South America)

and reaches its final destination in South America. The aforementioned open sources were only confirmed by successful actions against arms smuggling in South America. ${ }^{16}$

These facts indicate the need to fight against illegal arms manufacturers and smugglers in Croatia. Additional cases, listed below, illustrate this need:

- In March 2006, police discovered at V.Š. (33) thirty weapons, including guns, machine guns, and hunting arms.

- In November 2005, Slovenian police, in cooperation with the MUP, caught Bojan Repnik (a Slovenian national) and Tomislav Dobričević (a Croatian) near Rogaška Slatina, finding a total of thirty-seven kilograms of plastic explosives. Among the seized materials were seven kilograms of GOMA and two kilograms of EKO explosives like those used in the Madrid terrorist attacks of 11 March 2004.

- Zagreb and Rijeka were the main areas for police operations in June 2005 that resulted in the capture of a group of suspects who possessed nearly 300 kilograms of explosives, mines, automatic arms, and ammunition. The police also seized two kilograms of heroin in the raid.

- In August 2005, in the village of Mogorić, which is near the town of Gospić, several men with an arsenal of ammunition and a variety of explosives (including 9.5

16 Marin Dešković and Dragan Grdić, “A Group of Weapons Smugglers Captured,” Vjesnik (8 June 2006); available at www.vjesnik.hr/pdf/2006\%5C06\%5C08\%5C48A48.pdf. 
kilograms of explosives, half a kilogram of plastic explosives, and 300 grams of industrial explosives) were arrested.

- In the summer of 2005, in a coordinated operation by USKOK, MUP, and POA, thirteen people were arrested and an arsenal of firearms and explosives was seized, including twenty hand grenades, a chemical bomb, eleven rocket launchers, a few machine and sub-machine guns, a silencer, and various types of ammunition.

\section{Conclusion: What is the Current Situation?}

Available data suggest that current annual global revenues from illicit criminal activities are USD 100 to 300 billion from drug trafficking; USD 10 to 12 billion from the illegal dumping of toxic and other hazardous waste; and USD 7 billion from human smuggling. Available estimates suggest that corruption costs approximately USD 500 billion — or about one percent of global GNP—in the form of slower growth, reduced foreign investment, and lower profits. ${ }^{17}$

Of greatest concern, however, is the fact that the routes used to traffic people, drugs, and weapons can readily provide a suitable logistical infrastructure to terrorist groups and serve as a staging ground for future terrorist actions. These routes survive because they are not actively countered, due to inefficient administrations and corruption in the unstable states where they flourish. Accordingly, the states along these smuggling routes should receive particular attention. National governments should provide them with assistance in establishing strong law enforcement and governance mechanisms within their states.

Through an analytic review of the smuggling issue, primarily through Croatia and the larger region of South Eastern Europe, researchers should create information prerequisites for further investigation into this important issue. Therefore, it is necessary to describe, in a similar manner, the situation in the region on the basis of collected and integrated data and information; to set parameters to deal with smuggling; and to establish an integrated virtual system of regional supervision. Only by setting the right parameters and standards for virtual integration (which is extremely important) can smugglers of arms, drugs, and people in the region be efficiently countered. It is also necessary to build a system of analytic judgment. Finally, the system must be accessible to multinational forces that stand ready to respond rapidly and efficiently. ${ }^{18}$ As has been noted many times before, smuggling channels and their logistical operations can be used by terrorists to organize and carry out terrorist acts; therefore, smuggling - in all its forms - should be a top priority of international law enforcement agencies and of national governments everywhere, but particularly in the regions where these networks proliferate.

17 Available at http://infowar.net/cia/publications/globaltrends2015.

18 K. Antoliš, "Human Resources in Combating Terrorism,” Modern Traffic (Zagreb) 26:5 (September-October 2006): 285-384. 


\section{THE QUARTERLY JOURNAL}

\section{Bibliography}

Antoliš, K.. "Human Resources in Combating Terrorism." Modern Traffic (Zagreb) 26, no. 5 (2006): 285-384.

Antoliš, K.. "Prerequisites for Systematic Fighting of Terrorism." In National Security and Traffic Perspectives for the Republic of Croatia. Zagreb: Croatian Parliament, 2006.

Antoliš, K.. "Strategic Prerequisites for Partnership in Combating Terrorism." InEstablishing Referent Laboratory for Nuclear-Biological-Chemical Protection and System for Bio-monitoring in the Republic of Croatia. Zagreb: Institute Ruđer Bošković, 2006.

Dešković, Marin, and Dragan Grdić. "A Group of Weapons Smugglers Captured." Vjesnik(2006).

Jemrić, Ines. Violence Against Women. Zagreb: Ženska infoteka, 2003.

Marash, David. "Saddam's Serb Supplier: How our Last Enemy Has Been Arming our Next One." Washington Monthly (2003).

PKK and Terrorism: Drug Trafficking and Terrorist Organizations. In Assembly of Turkish-American Associations. Turkey, 1998.

Zornija, Alenko. "Weapons Smugglers under Protection of BH Politicians?" Vjesnik(2001). 